\title{
Kazanie I: O nieśmiertelności
}

\author{
2 Tm, 10: Jezus Chrystus, który zniszczył śmierć \\ i przez Ewangelię odsłonił życie i nieśmiertelność.
}

Nie będę dociekał, czy można uznać, że niektórzy starożytni filozofowie posiedli wiedzę o życiu wiecznym, czy też nie ${ }^{1}$. Tak czy inaczej, jestem

${ }^{1}$ W kolejnych numerach „Studiów z Historii Filozofii” rozpoczynamy druk przekładów kazań George’a Berkeleya (1685-1753), z których do tej pory znane jest polskiemu czytelnikowi tylko tzw. Jubileuszowe kazanie wygłoszone w Towarzystwie Krzewienia Ewangelii z 1732 roku (w krytycznym wydaniu A. A. Luce’a i T. E. Jessopa nosi ono numer IX), które ukazało się niedawno w przekładzie A. Grzelińskiego i M. Szymańskiej-Lewoszewskiej w tomie G. Berkeley, Pisma ekonomiczne i społeczne (Toruń 2016). Ogółem zachowało się 10 kazań, które Berkeley - filozof, ale też duchowny anglikański, a od 1734 roku biskup Cloyne wygłaszał do swych wiernych. Choć siłą rzeczy różnią się treścią i formą od publikowanych przezeń dzieł o tematyce ściśle filozoficznej (niekiedy stanowią one dość luźne notatki do kazań), zawierają cenne wskazówki interpretacyjne dotyczące Berkeleyowskiego systemu filozoficznego. Jednym z jego zasadniczych rysów było bowiem sięganie po argumenty filozoficzne w celu obrony i uzasadnienia religijnego światopoglądu, zagrożonego zdaniem Berkeleya materializmem i dążeniami racjonalistycznymi, które nawet jeśli miały prowadzić do ostania się religii naturalnej, rugowały religię objawioną. Choć najważniejsze i najbardziej znane dzieła Berkeleya niemal w całości poświęcone były problematyce ściśle filozoficznej, ich pełne tytuły nie pozostawiały wątpliwości co do ich apologetycznego celu: Traktat o zasadach poznania ludzkiego, $w$ którym docieka się przyczyny błędów i trudności w naukach, a także źródła sceptycyzmu, ateizmu i niereligijności oraz Trzy dialogi pomiędzy Hylasem i Filonousem, których celem jest wykazanie realności i doskonałości ludzkiej wiedzy, niematerialnej natury duszy oraz 
pewien, że nauczanie o życiu i nieśmiertelności nie było nigdy tak szeroko przyjmowane (current) i powszechne, jak po przyjściu naszego błogosławionego Zbawiciela. Choć bardzo trudno jest to pojąć, nawet jeśli zgodzilibyśmy się, że niektórzy wyjątkowo zdolni ludzie mogliby, dołożywszy starań, zdobyć wiedzę demonstratywną na temat tak ważkiej kwestii mocą samego rozumu, to jednak ci, którym brakuje bądź czasu, bądź zdolności potrzebnych do dokonania tak wielkiego i trudnego odkrycia, a którzy niewątpliwie

bezpośredniej Opatrzności Bożej przeciwko sceptykom i ateistom, oraz stworzenie metody, dzięki której nauki staną się łatwiejsze, pożyteczniejsze i bardziej zwięzłe. W przypadku kazań sytuacja jest odwrotna. Bezpośrednio dotyczą one problemów religijnych i teologicznych, a ich celem jest ugruntowanie wiary słuchaczy, jednak zawierają również treści filozoficzne. Na uwagę zasługuje także fakt, że Berkeley głosił kazania w ciągu całej swej działalności pisarskiej: pierwsze z nich, którego przekład tu drukujemy, pochodzi z początku roku 1708, a więc czasu krystalizowania się jego stanowiska filozoficznego. W tym okresie powstawały jego Dzienniki filozoficzne, w których opracowywał zręby głoszonego w Traktacie immaterializmu. Ostatnie kazanie, którego tekst znamy, pochodzi z roku 1751, a więc czasu, gdy przygotowywał ostatnie wydanie swych najważniejszych dzieł w A Miscellany (1752).

Niniejsze kazanie dotyczy wizji nieśmiertelnego życia obiecanego przez Boga oraz wskazuje na potrzebę rozbudzenia wiary przez rozmyślanie nad znikomością życia doczesnego. Niektóre argumenty dotyczące pobudek do wiary w życie wieczne Berkeley czerpie z Locke’owskich Rozważań dotyczących rozumu ludzkiego (1690): porównywanie przyjemności odległych i obecnych, konieczność uczynienia przedmiotem rozmyślań niedoli życia $\mathrm{w}$ porównaniu z będącym przedmiotem religijnej obietnicy wiecznym szczęściem. Warto zauważyć, że powstałe w tym samym czasie co owo kazanie wpisy w Dziennikach filozoficznych zawierają wiele odniesień do dzieła Locke’a: Berkeley początkowo akceptował bowiem Locke’owską teorię idei, stopniowo jednak stawał się wobec niej coraz bardziej krytyczny. W niniejszym kazaniu Berkeley zastanawia się nad słusznością Locke’owskiej tezy głoszącej, że dobro pojmowane jako źródło ludzkiego szczęścia motywuje do działania tylko wtedy, gdy człowiek uświadamia sobie jego brak, co jest źródłem niepokoju (uneasiness) i pragnienia jego zdobycia. W Dziennikach odnajdujemy to samo pytanie (wpis 423): „Skoro niepokój jest niezbędny, by zaprzęgnąc wolę do pracy, pytanie brzmi: jak dokonamy tego w niebie?” (G. Berkeley, Dzienniki filozoficzne, przeł. B. Żukowski, Wyd. słowo/obraz terytoria, Gdańsk 2007, s. 77). Odchodzenie irlandzkiego filozofa od poglądów Locke’a dobrze widać także chociażby w jego rozumieniu wieczności: w niniejszym kazaniu zdaje się rozumieć wieczność jako nieskończenie długi czas (na jego określenie używa też tradycyjnego, stosowanego jeszcze przez Locke’a terminu „trwanie” (duration)), podczas gdy w późniejszym okresie utożsamia wieczność z pozaczasowym trwaniem (por. G. Berkeley, Korespondencja z Samuelem Johnsonem, [w:] tenże, Próba stworzenia nowej teorii widzenia i inne eseje filozoficzne, przeł. A. Grzeliński i Translatorium IF UMK, WN UMK, Toruń 2012, s. 248 i nast.). Podstawa niniejszego przekładu: G. Berkeley, Sermons, [w:] The Works of George Berkeley, ed. A. A. Luce, T. E. Jessop, Th. Nelson, London-Edinburgh-Paris-Melbourne-Toronto-New York 1948-1985, t. 7, s. 9-15. Tytuł kazania pochodzi od wydawców angielskich, zaś przypisy - od tłumaczy.. 
stanowili największą część ludzkości, pozbawieni Objawienia musieli ciągle pozostawać w ciemności. Choćby nawet ci, którzy by prawdę tę dostrzegali, przekazali innym wynik swych rozumowań, to jednak nie znając przesłanek, nie można być nigdy pewnym wniosku, chyba że jego nauczyciel potrafiłby dokonywać cudów, aby kogoś przekonać. Dlatego jest oczywiste, że jeśli ci, którzy w ten sposób kierowali swymi myślami, dokonaliby jakichś odkryć dotyczących życia przyszłego, to niezależnie od tego, jak daleko sięgałby ich wzrok, światło musiało zostać zduszone w ich własnych sercach i nie stało się promieniem oświecającym całą resztę ludzkości aż do wzejścia tego Słońca sprawiedliwości, które przez Ewangelię odsłoniło życie i nieśmiertelność. Rozprawiając o tym, przestrzegać będę następującej metody. Po pierwsze, rozważę, jakie skutki objawienie to miało dla całego chrześcijańskiego świata; po drugie, zbadam jak to się dzieje, że nie ma ono większego wpływu na nasze życie i stosunki pomiędzy nami; po trzecie, ukażę, w jaki sposób może się ono stać bardziej skuteczne.

Jeśli chodzi o punkt pierwszy, można by sądzić, że nie trzeba daleko szukać skutków tak ważnego i powszechnego objawienia, objawienia, które poucza o wiecznym szczęściu bądź wiecznej nędzy, jakie są nieuchronnym losem każdego człowieka, przyniesionym przez Syna Bożego, poświadczonym przez cuda i świadectwo wszystkich uczonych teologów chrześcijańskich. Jeśli pośród pogan dokonywano dobrych czynów, nie mając na względzie niczego innego, jak tylko doczesne korzyści dla ludzkiej społeczności, jeśli niektórzy uważali, że cnota jest wystarczającą zapłatą za samą siebie, jeśli rozum i doświadczenie już dużo wcześniej przekonały świat o tym, jakie przykrości i zniszczenie mogą przynieść ludzkie przywary zarówno niegodziwcom, jak i całej ludzkości, to dlaczegóż człowiek nie miałby skłaniać się ku temu, co samo w sobie jest cnotą tak miłą i przynoszącą korzyści, jak ta, która wiąże się $\mathrm{z}$ chwalebną nagrodą życia wiecznego? Jacyż nikczemnicy byliby na tyle zatwardziali i głupi, by nie widzieć, że dodatkowa trwoga, wieczna śmierć i potępienie tym bardziej przekonują, że przywary są godne potępienia i szkodliwe? Można byłoby sądzić, że nauki, które zawdzięczmy naszemu Zbawcy, przynoszą w efekcie całkowitą poprawę obyczajów. Można byłoby wyobrażać sobie, że gdy tylko ludzie otworzą oczy, natychmiast przestaną myśleć o tej skazanej na zagładę ziemi i skierują się ku rozleglejszym widokom nowych przestrzeni życia i nieśmiertelności. Taką, powiadam, ktoś mógłby mieć nadzieję i tak mógłby przekonywać samego siebie. Lecz niestety! Obawiam się, że po dokładniejszym rozważeniu wszystko to okaże się płonnymi nadziejami i pustą spekulacją. 
Przyjrzyjmy się samym faktom. Zastanówmy się, proszę, czy my, chrześcijanie, aż tak bardzo przewyższamy starożytnych pogańskich Rzymian, jeśli chodzi o powściągliwość, męstwo, poczucie godności czy prawość? Czyż mniej niż nasi pogańscy przodkowie jesteśmy skorzy do pychy, skąpstwa, sporów i stronniczości? Czyż wśród nas, którzy wypatrujemy nieśmiertelności, dawna doktryna nakazująca jedynie jeść i pić, skoro jutro możemy umrzeć nie jest równie popularna, jak była zawsze? My, którzy należymy do chrześcijańskiego świata rozświetlanego blaskiem Ewangelii i czerpiemy naukę od Syna Bożego: czyż sami stanowimy świetlany przykład pokoju i cnoty dla nienawróconych jeszcze pogan? Czyż nie jest mało prawdopodobne i czy nie byliśmy zaskoczeni, słysząc, że czas się dopełnił i światło Ewangelii prowadzi każdego człowieka poprzez pobożność i cnotę ku wiecznemu szczęściu? Powiadam: czyż nie jest równie jasne i uderzające, że o tej porze dnia, w tym właśnie miejscu na świecie walczymy ze sobą o rzeczy doczesne i wydzieramy sobie wzajemnie z rąk tę oto odrobinę błota, skoro mamy przed sobą obraz nieba?

Przejdę teraz do zbadania przyczyn, dla których chrześcijanie są tak zadziwiająco zaślepieni. Sprawiają one, że darząca szczęściem nieśmiertelność ma tak mały wpływ na nas, a nic nieznaczące doczesne sprawy naszego żywota wpływają na nas w sposób tak przemożny i każą nam za sobą gonić. Na czym polega ten zadziwiający mechanizm naszych uczuć, które wprawiane są w ruch przez te nieistotne, niewiele znaczące przedmioty zmysłowe, podczas gdy zupełnie nie mogą tego uczynić rzeczy o nieskończonej wadze i znaczeniu? Gdyby tylko niebiosa zdołały rozbudzić nasze nadzieje i pragnienia rzeczy tak wielkich i wspaniałych, bez wątpienia wszystkie działania w naszym życiu w oczywisty sposób byłyby skierowane na jego osiągnięcie. Nie trzeba by już dłużej zastanawiać się, jakie skutki ma dla nas Objawienie naszego Zbawiciela. Każdy, kto widziałby chrześcijanina, od razu dostrzegałby w nim pielgrzyma, wędrującego przez naszą ziemię prostą ścieżką do nieba, tak bardzo byłby on bowiem obojętny na rzeczy życia doczesnego, tak przepełniałoby go życie przyszłe i tak bardzo byłby wolny od tego występku oraz zepsucia, które obecnie plamią naszą wiarę. Jeśli więc mamy odkryć, dlaczego nasze pragnienie życia i nieśmiertelności jest tak słabe i nieskuteczne, przyjrzyjmy się nieco przyczynie owych aż nazbyt rzucających się w oczy sprzeczności pomiędzy wiarą chrześcijan i naszym postępowaniem. Może dzięki temu uda

\footnotetext{
${ }^{2}$ Por. Iz 22, 13.
} 
nam się rozwiązać ową wielką zagadkę, że ludziom zdarza się myśleć, iż nieskończone, wieczne szczęście jest $\mathrm{w}$ ich zasięgu, a prawie niczego nie robić dla jego osiągnięcia. Moc racjonalnych pragnień jest proporcjonalna do wielkości dobra, do którego się dąży i, by tak rzec, do możliwości ich osiągnięcia. Pragnienie wzbudzane przez jakąkolwiek rzecz zależy od tego, jak bardzo jest ona pożądana, zaś tym, co czyni ją pożądaną, jest jej dobro czyli to, że jest ona odpowiednia dla naszej natury, oraz prawdopodobieństwa, z jakim możemy ją osiągnąć, albowiem to, co jest najwyraźniej poza naszym zasięgiem, nie pociąga nas, skoro pragnienie jest bodźcem do działania, a żadna rozumna istota nie kieruje swych działań ku temu, co uważa za niemożliwe do osiągniecia. Wiem, że pewien niedawno zmarły, niezrównany filozof przyjmuje, że wolę determinuje obecny w danej chwili niepokój umysłu, który jest zazwyczaj proporcjonalny do dobra danego przedmiotu ${ }^{3}$. Ja jednak nie mówię tu o zwierzęcych żądzach ludzi, ale o dobrze ugruntowanych racjonalnych pragnieniach, a z tego co zostało powiedziane, wynika, że bezpośrednio zależą one od doskonałości i pewności osiągnięcia odpowiadającego im przedmiotu. Tak więc przedmiot, który jest tylko w połowie tak dobry jak inny i który można osiągnąć w sposób dwakroć pewniejszy niż ten drugi, pożądany jest w tym samym stopniu co on. Zazwyczaj też tak samo ceni się te losy, w których wysokość nagrody jest proporcjonalna do ryzyka porażki. Opierając się na tej zasadzie, sprawdźmy teraz, jaką wartość powinniśmy przypisać obietnicom naszego Zbawiciela, a także z jakim stopniem gorliwości i pragnienia powinniśmy rozumnie podążać za tymi rzeczami, które Jezus Chrystus odsłonił za pośrednictwem Ewangelii. Aby to ukazać, powinniśmy, po pierwsze, rozważyć ich doskonałość i, po drugie, pewność naszego ich osiągnięcia po wypełnieniu warunków, pod jakimi zostały obiecane.

Po pierwsze zatem, tym, co obiecał nasz Zbawiciel, jest życie i nieśmiertelność, to znaczy, wyrażając rzecz językiem Pisma, wieczne szczęście, szczęście dorównujące naszym pragnieniom i to pragnieniom nieograniczającym się do owych paru przedmiotów, które są nam dane dzięki kilku ścieżkom niejasnej zmysłowej percepcji, lecz odpowiednie do zdolności, którymi Bóg zwieńczył naszą naturę i dzięki którym możemy stać się mieszkańcami niebios. Owo szczęście my, obdarzeni ciasnym umysłem śmiertelnicy, możemy w przyziemny sposób wyobrażać sobie jedynie jako zielone łąki, pachnące lasy, dające ulgę cienie, krystaliczne strumienie i inne przyjemne obrazy, jakie

${ }^{3}$ Zob. J. Locke, Rozważania dotyczące rozumu ludzkiego, II, 21, 31, przeł. B. Gawecki, Warszawa 1955, t. 1, s. 342. 
nasza fantazja zdolna jest zdobyć na tym padole łez. Czyni to ona jednak na próżno, nawet bowiem Apostoł, który został porwany do trzeciego nieba ${ }^{4}$, mógł nam dać jedynie taki opis, który choć dobitny, był całkowicie nieadekwatny. Owego szczęścia nie tylko oko nie widziało i ucho nie słyszało, ale też nie jest ono czymś, co mogłoby pojąć ludzkie serce ${ }^{5}$. $\mathrm{Z}$ tego też powodu ową szansę na dostąpienie dobra, tak niewyrażalnego i w niedający się pojąć sposób wielkiego, nawet jeśli nie jest ona wcale mała i niepewna, należy tym bardziej wziąć pod uwagę i przedkładać ponad największą pewność, z jaką możemy posiąść jakiekolwiek dobro doczesne (sublunary), ponieważ różnica wielkości i wspaniałości jednego i drugiego dobra znakomicie przewyższa różnicę szansy na ich osiągnięcie. Dlatego też nie ma potrzeby szczegółowo rozprawiać nad drugą kwestią, którą mieliśmy się zająć, a mianowicie pewnością, z jaką możemy dostąpić nagrody; nagroda ta jest wystarczająco wielka, abyśmy poświęcili jej całą naszą troskę, zabiegi oraz namiętności, nawet jeśli szansa na jej zdobycie byłaby zgoła jak najmniejsza.

Niezależnie od tego, jaka zwierzęca namiętność ma wpływ na jednych, na innych zaś bezmyślność i głupota, wierzę, że nie ma wśród nas ludzi, którzy nie uważaliby, że to, iż Ewangelia zawiera prawdę, jest równie prawdopodobne jak to, że zawiera fałsz. Jestem pewien, że nikt nie powie, iż szansa, że nie zawiera ona prawdy, jest jak dwa do jednego. Gdzie jednak na szali leży życie i nieśmiertelność, tam w bojaźni i drżeniu powinniśmy obstawać przy nich, nawet jeśli szanse na to, że zostaniemy oszukani, wynoszą sto do jednego, a nawet jeśli szansa na to, że zdobędziemy tak wspaniałą nagrodę, byłaby choćby nieskończenie mała, a temu nie może zaprzeczyć nikt, największy nawet libertyn czy najbardziej zaślepiony ateista. Jasne jest zatem, że gdyby nasze pragnienia rzeczy odsłoniętych przez Ewangelię były takie, jak zgodnie ze ścisłym rozumowaniem być powinny, to nic nie mogłoby być bardziej żywe i intensywne, pewne i stałe niż one. A z tego, że istnieje pragnienie przynoszące niepokój i odpowiadające mu niespokojne działanie, z konieczności wynika, że życie i nieśmiertelność powinniśmy uczynić naszą zasadniczą troską, kierując ku nim wszystkie nasze myśli, nadzieje i dążenia. Ale skoro ewidentnie jest zupełnie inaczej, skoro błahe sprawy obecnego życia zajmują nas tak bardzo, że wręcz nie mamy czasu, by rzucić okiem w przy-

\footnotetext{
${ }^{4}$ Por. 2 Kor 12, 2-3. Wspomnianym Apostołem jest św. Paweł, jednak Berkeley powołuje się na jego pisma niedokładnie - św. Paweł jedynie słyszał o człowieku porwanym do trzeciego nieba.

${ }^{5}$ Por. 1 Kor 2, 9.
} 
szłość i spojrzeć poza grób, to oczywistą tego konsekwencją jest to, że nie posiadamy racjonalnego pragnienia rzeczy odsłoniętych przez naszego Zbawiciela, a to dlatego, że nie ćwiczymy w nich naszego umysłu, jak czynimy to w bardziej pospolitych sprawach. Nigdy nie myślimy o przyszłym życiu i nieśmiertelności i nigdy nad nimi nie rozważamy; stąd właśnie bierze się to, że ich objawienie ma tak mały wpływ na nasze życie i wzajemne stosunki. Oto dlaczego ludzie, którzy w innych sprawach rozumują zupełnie dobrze, działają tak bezmyślnie i opornie w sprawach o większej wadze i dlaczego okazują się tak głusi i głupi w odniesieniu do ciągłych wezwań i obietnic Boga. Myślę, że obok zwykłych przeszkód świata cielesnego i Szatana, można tu wskazać na dwie przyczyny, po pierwsze - nie mamy ustalonego wyobrażenia o przyjemnościach nieba i dlatego nie mogą nas one tak mocno pobudzać do rozmyślania nad nimi, po drugie - myśli się o nich mniej, gdyż wyobrażamy sobie, że dzieli nas od nich ogromna odległość. Co do punktu pierwszego - to prawda, że nie możemy mieć w tym życiu ustalonego wyobrażenia o przyjemnościach życia przyszłego, a to dlatego, że ich przewyższająca wszystko, transcendentna natura nie jest odpowiednia dla naszych obecnych - słabych i ograniczonych - władz poznawczych. Sądzę jednak, iż powinniśmy zadowolić się tym, że ich doskonałość przekraczać będzie zakres naszej wyobraźni, że będą one takie, jak mądry, potężny i dobry Bóg uzna za właściwe, by zaszczycić i uszczęśliwić nimi swoich świętych. Gdyby Wszechmocny natchnął nas nowymi zdolnościami i pozwolił zakosztować tych niebiańskich radości, nie mogłoby już być dla nas dłużej życia na tym świecie, nie moglibyśmy cieszyć się jego rzeczami, ale musielibyśmy obumierać i usychać z nieustannej tęsknoty za życiem przyszłym. Ponadto nie mogłaby istnieć żadna cnota, żadna wada, nie bylibyśmy już dłużej wolni w naszych działaniach, ale w nieodparty sposób śpieszylibyśmy, by czynić i cierpieć wszystko dla osiągnięcia tak wielkiego szczęścia. Co do drugiego powodu, dla którego zaniedbujemy nasze przyszłe życie, tzn. tego, że jest ono od nas niezmiernie odległe, to przyznam, że co prawda skłonni jesteśmy tak o nich myśleć, sądzę jednak, że całkiem bez powodu. Świat, w którym żyjemy, można niesłusznie przyrównać do świątyni fałszywego proroka Aleksandra opisanej przez Lukiana ${ }^{6}$. Miała ona przednie i tylne drzwi, pomiędzy którymi przechodziło się w ciągłym ruchu, trudno było zatem zatrzymać się i dostrzec, co dzieje się w środku. Dokładnie to samo widzimy na co dzień: wielu tłoczy się, przybywając na ten świat, wielu z niego odchodzi, nie mamy dość czasu, aby się rozejrzeć

\footnotetext{
${ }^{6}$ Chodzi o dialog Lukiana z Samosaty, Aleksander czyli fałszywy prorok.
} 
dokoła i gdyby zostawić nas samych sobie tak, by każdy zdany był jedynie na swe własne doświadczenie, wówczas nic niemal nie wiedzielibyśmy zarówno na temat ziemi, jak i istot, które Wszechmogący na niej umieścił, tak szybko przechodzimy od łona, z którego przyszliśmy, do grobu. A jednak tak bardzo brak nam rozumu, że swoje życie, ów krótki czas (duration), traktujemy tak, jak gdyby był on dłuższy od samej wieczności. Gdyby jednak przyjąć, że obiecane szczęście nie byłoby nigdy tak od nas odległe i nie wydawałoby się przez to tak znikome - cóż wtedy? Czy rzeczywiście przedmiot, który z daleka wydaje się mały, taki właśnie realnie jest ${ }^{7}$ ? Zapytuję więc: czy człowiek winien oceniać przedmioty takimi, jakimi rzeczywiście są same w sobie, czy też takimi, jakimi się wydają?

Przechodzę teraz do trzeciej zapowiadanej kwestii, a mianowicie do wykazania, w jaki sposób objawienie przez naszego Zbawiciela życia i nieśmiertelności może w większy sposób wpłynąć na nasze życie i relacje między ludźmi. Gdybyśmy tylko w większym stopniu pożądali tego, co wyjawia Ewangelia, bez wątpienia stałoby się jasne, że nasze życie i my sami powinniśmy pragnąć prawości tak samo, jak nasze serce dopomina się o wodne zdroje. Aby zatem wzbudzić w sobie ów zapał i pożądanie życia i nieśmiertelności, potrzeba tylko, abyśmy, jak zostało to ukazane, skierowali na nie swój wzrok i myśleli o nich z właściwą uwagą ${ }^{8}$. Niechby każdy z nas tylko otworzył swe oczy i ujrzał przed sobą dwie drogi: jedną, wiodącą prosto, pełną pokoju ścieżką pobożności i cnoty aż ku życiu wiecznemu, i drugą, pełną wybojów i zakrętów ludzkich przywar, która kończy się wieczystą śmiercią. Jak powiadam, niechaj ludzie tylko rozejrzą się wokół i rozumnie oraz rozważnie spojrzą na obie te drogi, potem zaś niech wybiorą tę, którą wolą. Szacowanie i ważenie tego, co przeznaczył nam Wszechmocny, nie jest wcale czymś błahym. Gdyby ktoś zaoferował nam transakcję, która mogłaby nam przynieść zysk na tym świecie, bez wątpienia uznalibyśmy, że jest ona warta namysłu. Gdy zaś wieczny Bóg oferuje nam szczęście tak bezgraniczne, jak bezgraniczne są nasze pragnienia i tak wieczyste, jak nieśmiertelne są nasze dusze, gdy wysyła swego ukochanego Syna, aby przekazał nam ową ważną wiadomość, czy mamy tkwić niewzruszenie pogrążeni w głupocie? Czy koniecznie musimy zasługiwać na wyrzuty, że życie i nieśmiertelność są niczym perły rzucone

7 Taką samą argumentację można znaleźć w Rozważaniach Locke’a (II, 21, 63, wyd. cyt., t. 1, s. 377).

${ }^{8}$ J. Locke, Rozważania dotyczace rozumu ludzkiego, II, 21, 34, wyd. cyt. t. 1, s. 344. 
przed wieprze ${ }^{9}$ ? Prawdą jest, że większość ludzi odczuwa szczególny wstręt przed myśleniem, a zwłaszcza, że trudzenie swej głowy rozmyślaniami na temat życia po śmierci jest obecnie bardzo niemodne. Świat przyszły niewiele zajmuje nasze myśli, a jeszcze mniej o nim rozprawiamy. Nasze życie wypełnia przede wszystkim zajmowanie się bogactwami, przyjemnościami i zdobywaniem wysokich urzędów, ze wszystkich stron wystawiamy się na pokusy zmysłów, które nigdy nie przestają odwodzić naszej uwagi od bardziej odległego dobra. Niechby nawet jednak zadanie to nigdy nie było równie niemodne, przykre i znojne jak teraz, przecież jeśli ktoś chce cieszyć się niebem w przyszłym życiu, musi się nad tym zastanowić. Musi wyzwolić się z pęt zmysłów i przyjemności, aby od czasu do czasu poważnie pomyśleć na temat wieczności, skierować swe spojrzenie na czekającą go nagrodę jako odpłatę za jego czyny. Krótko: kto nie postawił, że zaślepiony podąży w dół piekieł, musi od czasu do czasu rozejrzeć się wokół siebie, gdy stoi na stałym gruncie i z doczesnego świata dojrzeć świat, który go czeka, w porównaniu z którym cała ziemia wraz ze wszystkim, co się na niej znajduje, jest, wyrażając się pięknym językiem proroka, jak kropla wody u wiadra i jak pyłek na szali ${ }^{10}$, mniej niż niczym.

Błagamy Cię, Wszechmogący Boże, by słowa, które dzisiaj usłyszały nasze uszy, dzięki Twej łasce mogły zostać wyryte w naszych sercach tak, aby zrodziły owoc dobrego życia, my zaś dzięki temu mogli darzyć szacunkiem i wychwalać Twe imię przez Jezusa Chrystusa, Pana naszego.

Łaska naszego Pana Jezusa, miłość Boga i jedność Ducha Świętego niechaj będą z nami na wieki.

Kaplica kolegium. Niedziela wieczór, 11 stycznia 1708.

Przekład i opracowanie: Adam Grzelinski Uniwersytet Mikołaja Kopernika, Toruń, Polska e-mail: grzelinski@wp.pl

Dariusz Kucharski Uniwersytet Kardynała Stefana Wyszyńskiego, Warszawa, Polska e-mail: d.kucharski@uksw.edu.pl

\footnotetext{
${ }^{9}$ Mt 7, 6.

${ }^{10} \mathrm{Iz} 40,15$.
} 